\title{
CHRYSTOLOGICZNY DOGMAT CHALCEDONU WE WSPÓŁCZESNEJ TEOLOGII PASTORALNEJ
}

Zamysł przedstawienia tego tematu zrodził się w czasie uczestniczenia autora w obradach sympozjum naukowego zorganizowanego przez Międzywydziałowy Zakład Badań nad Antykiem Chrześcijańskim KUL na temat Tajemnica Wcielenia w nauce Ojców Kościota, które miało miejsce w Lublinie w dniach od 27 do 28 listopada 2000 roku. Wówczas zdał on sobie sprawę ze znaczącego wpływu, jaki na rozwój współczesnej teologii pastoralnej wywarło przyjęcie chrystologicznej zasady bosko-ludzkiej, wypracowanej przez Sobór Chalcedoński (451 r.) ${ }^{1}$. Dokonał tego w latach czterdziestych naszego stulecia Franz Xaver Arnold, profesor teologii pastoralnej uniwersytetu w Tybindze. Ten wybitny pastoralista, jak napisał ks. F. Blachnicki w encyklopedycznym artykule jemu poświęconym $^{2}$, wykazał, że „Chrystus, Bóg-Człowiek i Pośrednik zbawienia, powinien być we wszystkim prototypem kośc[ielnego] pośrednictwa zbawczego, czyli duszpasterstwa; powinno być ono zawsze zorientowane według dogmatycznie poprawnego, pełnego obrazu Chrystusa, Boga-Człowieka, unikając przesadne-

${ }^{1}$ Formuła dogmatyczna wówczas przyjęta brzmi następująco: ,,[...] jednego i tego samego Chrystusa Pana, Syna Jednorodzonego należy wyznawać w dwóch naturach, bez zmieszania, bez zmiany, bez rozdzielenia i rozłączenia. Nigdy nie zanikły różnice natur przez ich zjednoczenie, ale została zachowana właściwość obu, tworzących jedna osobę i jedną hipostazę. Nie można Go dzielić na dwie osoby ani ich w Nim rozróżniać, ponieważ jest jeden i ten sam Syn jednorodzony, Słowo Boże, Pan Jezus Chrystus, jak przedtem prorocy nauczali o Nim, jak sam Jezus Chrystus o tym nas pouczył i jak nam przekazał Symbol Ojców" (Breviarium fidei. Wybór doktrynalnych wypowiedzi Kościoła, VI 8, oprac. S. Głowa - I. Bieda, wyd. 2, Poznań 1988, 8 s. 226). W 1500. rocznicę tego Soboru ukazało się monumentalne dzieło, w którym omówiono szczegółowo historię i teologię dogmatu: Das Konzil von Chalkedon. Geschichte und Gegenwart, Bd. 1-3, hrsg. A. Grillmeier H. Bacht, Würzburg 1951-1954. Do dziś poszczególne zagadnienia chrystologiczne pozostają przedmiotem wnikliwej analizy teologów, o czym świadczą choćby opublikowane na ten temat dokumenty Międzynarodowej Komisji Teologicznej: Wybrane zagadnienia z chrystologii, w: Od wiary do teologii. Dokumenty Międzynarodowej Komisji Teologicznej 1969-1996, red. J. Królikowski, Kraków 2000, 111-132; Teologia, chrystologia, antropologia, tamże, s. 133-150; Świadomość, jaka Jezus miat o sobie samym, tamże s. 237-250. Tytułem przykładu wystarczy odnieść Czytelnika do hasła Chrystologia, które opracowano w Encyklopedii Katolickiej (EK III 304-323).

${ }^{2}$ F. Blachnicki, Arnold Franz Xaver, EK 942-943. 
go antropocentryzmu lub teocentryzmu przez jednostronne zaakcentowanie w Chrystusie bądź jego bóstwa, bądź człowieczeństwa, co prowadzi w konsekwencji do teologiczno-pastoralnego supernaturalizmu i kwietyzmu albo naturalizmu i pelagianizmu. Przeprowadzając wnikliwe analizy konkretnych, hist[orycznych] form działania Kościoła w świetle teol[ogicznej] zasady chrystologicznej (bosko-ludzkiej), A[rnold] dał początek nauk[owej] teologii duszpasterstwa (czyli teologii działania, urzeczywistniania się Kościoła w teraźniejszości) i zarazem wprowadził do tej dyscypliny metodę dedukcyjno-indukcyjną".

Wydaje się, że warto zwrócić uwagę i zaznaczyć ten etap wpływu starożytnej, dogmatycznej refleksji Kościoła na współczesny rozwój teologii pastoralnej, stosunkowo młodej dyscypliny, dzięki której udało się ją wydobyć z kryzysu, w jaki popadła tuż po wprowadzeniu jej na uniwersytety i do szkół wyższych kształcących przyszłych duszpasterzy. W związku z tym w części pierwszej zajmiemy się przedstawieniem rozwoju teologii pastoralnej do czasu Arnolda, a następnie podejmiemy próbę analizy ujęcia teologii pastoralnej w świetle zasady bosko-ludzkiej, którą wypracował tybindzki Teolog. Na koniec zwrócimy uwagę na przejęcie tej zasady przez współczesną polską teologię pastoralną i próbę jej zaktualizowania na podstawie wprowadzenia personalistycznej koncentracji w teologii.

1. Teologia pastoralna do czasu Franciszka Ksawerego Arnolda. Teologia pastoralna została wprowadzona na uniwersytety w 1772 r. za sprawą Johanna Franza Rautenstraucha (1734-1785), który w ramach reformy szkolnictwa i studiów, przeprowadzonej za panowania Marii Teresy w ówczesnym Cesarstwie Austro-Węgierskim, dokonał odnowy studiów teologicznych ${ }^{3}$. Ponieważ brak było wówczas odpowiedniej literatury pastoralnej, za pomocą której można by było prowadzić wykłady, przeto Rautenstrauch dokonał tłumaczenia dzieła Johannesa Opstraeta pt. Pastor bonus ${ }^{4}$, w którym duszpasterz przedstawiony był jako pośrednik pomiędzy Bogiem a czlowiekiem. Natomiast

${ }^{3}$ Dnia 4 V 1774 r. przedstawił cesarzowej Marii Teresie Entwurf einer besseren Einrichtung theologischer Schulen, który zaczął obowiązywać 1 VIII 1774 r. i został opublikowany 3 X tegoż roku pod zmienionym tytułem jako Verfassung der theologischen Facultät (W. Schneider, Pastoraltheologie im Kontext der Studienreform Franz Stephan Rautenstrauchs, w: Wege der Pastoraltheologie. Texte einer Bewusstwerdung, Bd. 1, hrsg. A. Zottl - W. Schneider, Eichstätt 1987, s. 16 (skrót: WPTh I); por. J. Müller, Der pastoraldidaktische Ansatz in Franz Stephan Rautenstrauchs „Entwurf zur Einrichtung theologischer Schulen". Wien 1969).

${ }^{4}$ Por. Pastor bonus, seu idea, officium, spiritus et praxis pastorum, Mecheln 1689; K. Baumgartner, Der Wandel des Priesterbildes. Beiträge der pastoraltheologischen Literatur vor allem des 17. und 18. Jahrhunderts, w: Pastoraltheologie. Ein entscheidender Teil der josephinischen Studienreform 1777-1977, s. 173-190; H. Schuster (Die Geschichte der Pastoraltheologie, w: Handbuch der Pastoraltheologie, Bd. I, hrsg. F. X. Arnold, Freiburg-Basel-Wien 1964, s. 47 przyp. 1) podaje, że dzieło Opstraeta zostało już w 1764 r. przetłumaczone na j. niemiecki przez bpa Firmiana $z$ Passau, ale w 1766 r. zostało przez Święte Oficjum zakazane z racji tendencji jansenistycznych: zob.: 
w pracy samego Rautenstraucha, w Tabelarycznym zarysie teologii pastoral$n e^{5}$, ta wiodąca idea została podkreślona jeszcze dobitniej. Ujmował on bowiem tę dziedzinę wiedzy teologicznej jako ,pouczenie o obowiązkach urzędu pasterskiego i ich wypełnianiu" ". Samą zaś pastoralną dzielił, zgodnie z ówczesnym stanem wiedzy, na trzy części: O obowiązkach nauczania (Von der Unterweisungspflicht), $\mathrm{O}$ obowiązkach administrowania (Von der Verwaltungs- und Ausspendungspflicht), O obowiązku budowania swoim przykładem (Von der Erbauungspflicht $)^{7}$. Ks. Franciszek Blachnicki dokonując krytycznej analizy dokonań Rautenstraucha stwierdził, że ,nie można tu [...] mówić o właściwej »teologii « pastoralnej”, bo ta nowa dziedzina wiedzy teologicznej ,nie analizuje bowiem duszpasterstwa w świetle Objawienia, nie ustala zasad dla działalności duszpasterskiej na drodze teologicznej refleksji”" . Za F. K. Arnoldem i H. Schusterem oświadczył, że ,nieeklezjologiczny punkt wyjścia zaciążył fatalnie nad tradycyjną koncepcją teologii pastoralnej. Znalazła się ona w prawdziwym błędnym kole, stawiając u swoich podstaw pojęcie »pasterza« $\mathrm{i}$ »duszpasterstwa« jako swoją zasadę formalną. Zamiast bowiem pytać się w świetle is to ty Kościoła, jaka jest istota »pasterza«i »duszpasterstwa«, próbowała ona z powyższych pojęć wydedukować określenie istotnych rysów działalności Kościoła, a nawet i samego Kościoła"9.

Konstatacja ta zwraca uwagę na konieczność eklezjologicznej dedukcji teologii pastoralnej, czyli wywiedzenia z ujęcia (rozumienia) Kościoła, odpowiadającego jego aktualnej samoświadomości, koncepcji samodzielnej dyscypliny teologicznej (teologii pastoralnej) i wynikającej z niej koncepcji działania Kościoła (jego zbawczej posługi). Takie ujęcie - eklezjologiczne - wypracował w dziewiętnastym stuleciu tybindzki teolog, Anton Graf $(1814-1867)^{10}$. Wy-

A. Suchart, Der „Pastor bonus” des Johannes Opstraet. Zur Geschichte eines pastoraltheologischen Werkes aus der Geisteswelt des Jansenismus, Wien 1972.

${ }^{5}$ Por. F. S. Rautenstrauch, Tabellarischer Grundriß der in deutscher Sprache vorzutragenden Pastoraltheologie. WPTh I 27-34.

${ }^{6}$ WPTh I 27.

7 Tamże s. 28-34; por. F. Blachnicki. Teologia pastoralna ogólna, cz. 1: Wstẹp do teologii pastoralnej. Teologiczne zasady duszpasterstwa. Lublin 1970, s. 4 (skrót: Blachnicki, TPO I).

${ }^{8}$ Blachnicki, TPO I 5; por. tenże, Teologia pastoralna ogólna, cz. 2: Eklezjologiczna dedukcja teologii pastoralnej, Lublin 1971, s. 17 (skrót: Blachnicki, TPO II); M. Marczewski, Posługa zbawcza Kościoła w ujęciu ks. Franciszka Blachnickiego, Lublin 2000, 113-117; R. Kamiński, Historyczny rozwój teologii pastoralnej, w: Teologia pastoralna, t. 1: Teologia pastoralna fundamentalna, red. R. Kamińskiego, Lublin 2000, 61-65 (skrót: Kamiński, TP I).

${ }^{9}$ F. Blachnicki, Idea Kościota we wspótczesnej literaturze teologiczno-pastoralnej, SSTH 4(1971), s. 40 (podkr. moje: M. M.). Uważa on, że owo „pastoralno-teologiczne apriori” zaciążyło nie tylko nad ,początkami teologii pastoralnej i nad całym jej rozwojem”, ale „trwa aż do naszych czasów i ciągle, chociaż już nie w tak jaskrawej formie, zagraża wypaczeniem tej dyscyplinie" (tamże s. 58; por. Blachnicki, TPO II 42).

${ }^{10}$ J. Dyl, Graf Anton,. EK VI 30-31. Ksiądz Blachnicki pisał, że był on tym człowiekiem, wielkim i genialnym, który ,w połowie XIX wieku dokonal prawdziwego »przewrotu kopernikań- 
szedł on z wypracowanego przez tzw. szkołę tybindzką rozumienia historii, teologii i Kościoła. Znawcy problemu wskazują na J. S. Dreya, J. B. Hirschera i J. A. Möhlera, jako tych, którzy poprzez swe prace starali się wpłynąć na odnowę teologii w ogóle, a poprzez nią duszpasterstwa ${ }^{11}$. W nawiązaniu do osiągnięć tej szkoły ujmuje teologię jako naukową samoświadomość Kościoła: Kościół jest podmiotem i zarazem przedmiotem teologii ${ }^{12}$. Jest przedmiotem teologii w potrójnym aspekcie: w swoim historycznym stawaniu się, w swojej niezmiennej istocie oraz w swoim budowaniu się w przyszłość, dokonującym się w teraźniejszości ${ }^{13}$. Tym trzem ujęciom Kościoła odpowiadają trzy części teologii, które winny następować po sobie: teologia historyczna, systematyczna i praktyczna. Jedne $\mathrm{z}$ nich posiadają charakter czysto naukowy, inne - praktyczny ${ }^{14}$. Teologia praktyczna jest nauką i teorią samobudującego się Kościoła lub też nauką o kościelnych, bosko-ludzkich czynnościach zmierzających do budowania się Kościoła ${ }^{15}$.

Wypracowawszy tę definicję teologii pastoralnej (praktycznej), Graf nadał jej również status samodzielnej dyscypliny naukowej, w której z istoty Kościoła można wyprowadzić „zarówno cel jego działania, jak i główne środki”"16. Teologię pastoralną pojmuje Graf jako „teorię rządzenia Kościołem oraz posługi kościelnej. Działalność pierwsza związana jest szczególnie z hierarchią, druga z kapłaństwem »urzędowym «w ogólności" ${ }^{17}$. W innym miejscu pisze Sługa

skiego « w rozwoju teologii pastoralnej, ukazując jej całkiem nowe perspektywy" (Blachnicki, TPO II 42; por. Blachnicki, TPO I 11); zob. Marczewski, jw. s. 117-120; Kamiński, TP I 66-68.

11 Por. Blachnicki,-Idea Kościoła we wspótczesnej literaturze teologiczno-pastoralnej s. 58; N. Mette, Theorie der Praxis. Wissenschaftsgeschichtliche und methodologische Untersuchungen zur Theorie-Praxis-Problematik innerhalb der praktischen Theologie, Düsseldorf 1978, s. 33. O wpływie tych teologów na rozwój myśli teologiczno-pastoralnej Grafa zob. N. Mette, Die Tübinger pastoraltheologische Schule, w: Von der Pastoraltheologie zur Praktischen Theologie, hrsg. E. Weinzierl - G. Griesl, Salzburg-München 1975, 75-82.

12 A. Graf, Sechs und dreissig Sätze aus der Praktischen Theologie, WPTh II 33.

13 Tamże.

14 Tamże. Podkreślenie aspektu praktycznego teologii praktycznej nie oznacza bynajmniej, że należy przypisać jej mniejsze znaczenie niż naukom o charakterze bardziej teoretycznym, naukowym. Drey uwazal, ze teologia jako taka ,im emmintenten Sinne praktisch ist”. W związku z tym Mette (Die Tübinger pastoraltheologische Schule s. 78) pisze m.in.: „Diese Formulierung ähnelt der von Schleiermacher vorgenommenen Bestimmung der Theologie als einer »positive(n) Wissenschaft«, die es zur Aufgabe habe, "zur Lösung einer praktischen Aufgabe « beizutragen".

15 „Die praktische Theologie ist die Wissenschaft und Theorie der sich selbsterbauenden Kirche, oder der kirchlichen, göttlich-menschlichen Thätigkeiten zur Erbauung der Kirche" (Graf, jw. s. 34).

${ }^{16}$ Graf, jw. s. 34; Blachnicki, TPO II 45, por. Mette, Die Tübinger pastoraltheologische Schule, s. 84 .

17 Graf, jw. s. 34; Blachnicki, TPO II 46, por. Kamiński, Wprowadzenie do teologii pastoralnej, Lublin 1992, 24-26. Jeśli chodzi o systematyczne przedstawienie struktury przedmiotu materialnego teologii pastoralnej w ujęciu Grafa, to w dostępnej literaturze przedmiotu posiadamy dwa takie opracowania. Pierwsze przedstawił H. Schuster (Die Geschichte der Pastoraltheologie, s. 60-62), 
Boży, że są to ,jakby dwie płaszczyzny budowania Kościoła, ściśle jednak ze sobą zespolone, albowiem budowanie Kościoła »ogólnego« zmierza ostatecznie i służy budowaniu wspólnoty lokalnej (gminy), a budowanie wspólnoty lokalnej stoi w służbie wspólnoty ogólnokościelnej”"18 . Jak już wcześniej powiedzieliśmy, wybitny polski pastoralista, Sługa Boży ks. Franciszek Blachnicki (1921-1987) znaczenie dokonań Antoniego Grafa w rozwoju teologii określił mianem „przewrotu kopernikańskiego” i wręcz stwierdził, że „,koncepcja Grafa wydaje się być ujętą tak zasadniczo i głęboko, że można się pytać tylko o jej udoskonalenie w dalszym rozwoju, a nie o jej słuszność i zasadniczość w ogóle" 19 . Przekonanie to uzasadnił, wskazując na trzy racje, które decydują o aktualności eklezjologicznej dedukcji teologii pastoralnej Grafa. Są to: (a) Jasne i konsekwentnie przeprowadzenie tezy, że Kościół i jego istota ma być podstawą dedukcji koncepcji teologii pastoralnej i duszpasterstwa; (b) Ujęcie celu działania Kościoła w aspekcie formalnym i materialnym. W ujęciu formalnym cel działania Kościoła wyrasta z woli i istoty Chrystusa, Jego Ducha, Kościoła, parafii (gminy) i poszczególnych wiernych. W ujęciu materialnym celem działania Kościoła jest jego budowanie, które dokonuje się w Duchu Świętym. Prowadzi on wiernych do zespolenia się w parafiach (gminach), a poprzez nie w całym Kościele; (c) Środkami, które prowadzą do tego celu są przepowiadanie wiary, kult (liturgia) oraz dyscyplina ${ }^{20}$. Podobne stanowisko zajmuje Werner Schneider, który uważa, że przedstawiony przez Grafa zarys pastoralnej do dzisiaj zaskakuje swą aktualnością, ponieważ „także współczesna teologia praktyczna winna uzasadniać siebie jako dyscyplinę konieczną i teologiczną"21.

\section{Teologia pastoralna w świetle zasady bosko-ludzkiej Franciszka Ksawe-} rego Arnolda. Ujęcie Grafa nie zostało jednak podjęte przez pastoralistów, a nawet dość szybko zapomniane. Ten stan rzeczy trwał do czasu II wojny światowej, to znaczy do rozpoczęcia przez innego tybindczyka, ks. Franciszka Ksawerego Arnolda (1898-1969), studiów nad naturą, historią i teologią działalności duszpasterskiej ${ }^{22}$. W literaturze teologiczno-pastoralnej określa się go

drugie - W. Schneider (Das pastoraltheologische Werk Anton Grafs, WPTh II 24-25). Tak jedno, jak drugie stanowi próbę uporządkowania na podstawie myśli Grafa rozproszonych w różnych częściach jego dzieła.

${ }^{18}$ Blachnicki, TPO II 51.

19 Blachnicki. TPO II 52.

${ }^{20}$ Por. tenże, TPO II 49-51.

21 Das pastoraltheologische Werk Anton Grafs, s. 25-26.

${ }^{22}$ W 1942 r. opublikował w „Theologische Quartalschrift” podstawowy dla jego twórczości teologiczno-pastoralnej artykuł pt. Das Prinzip des Gott-menschlichen und seine Bedeutung für die Seelsorge 123(1942) 145-176, a w latach 1943-1946 w tymze czasopiśmie cykl artykułów zatytułowanych: Das Gott-menschliche Prinzip der Seelsorge in pastoral-geschichtlicher Entfaltung ThQ 124(1943) 99-133, 125(1944) 57-80, 126(1946) 43-85; por. F. Blachnicki, Pośrednictwo zbawcze 
jako kontynuatora Grafa: „podtrzymując w zasadzie koncepcję Grafa, wzbogaca ją o próbę zakotwiczenia jej w dogmacie chrystologicznym"23, a konkretnie w nauce o Chrystusie Bogu-Człowieku ${ }^{24}$, która w jego przekonaniu, jako głęboko zakorzeniona w chrześcijaństwie, że winna stać się prototypem kościelnego pośrednictwa ${ }^{25}$.

Odpowiadając na pytanie, czym jest i być powinna teologia pastoralna ${ }^{26}$, stwierdza, że nie może być nauką wykorzystującą osiągnięcia teologii biblijnej, historycznej i systematycznej do celów duszpasterskich, bo musiałaby nosić miano techniki pastoralnej. Jest dyscypliną teologiczną, ponieważ potrafi wskazać na swój własny przedmiot, który stanowią formy działania Kościoła, a na które składają się ,słowo, sakrament i duszpasterstwo w szerokim tego słowa znaczeniu". Jej zadanie polega na takim dostosowaniu i wypracowaniu form przepowiadania, przekazu Ewangelii i realizowaniu dzieła zbawczego, by odpowiadały wymogom czasu i gwarantowały samobudowanie Kościoła w przyszłości ${ }^{27}$.

To nowe rozumienie teologii pastoralnej wiązało się ściśle z nowym, ,uniwersalnym" rozumieniem Kościoła, które w swych zasadniczych założeniach było bliskie ujęciu Grafa. Jest to więc zgromadzenie, „Vollversammlung” - tak powie Arnold - wszystkich ochrzczonych, którzy są „podmiotem i odpowiedzialnymi za formy jego działania"28. Całościowe ujęcie duszpastersko działającego Kościoła wymaga, zdaniem tybindzkiego Pastoralisty, ,zakorzenienia w dogmatycznym nauczaniu o Chrystusie jako Bogu Człowieku [...], Pośredniku, którego religia jest religią pośrednictwa, a Jego pośrednictwo - zgodnie

Kościoła w ujęciu Franciszka Ksawerego Arnolda. Problem zasady formalnej teologii pastoralnej. Lublin 1965 (mps BKUL) s. 16 (skrót: Blachnicki, Pośrednictwo).

${ }^{23}$ Blachnicki, TPO II 53-56; tenże, Idea Kościoła we wspótczesnej literaturze teologicznopastoralnej s. 66.

${ }^{24}$ Por. K. Delahaye, Überlegungen zur Neuorientierung der Pastoraltheologie heute, w: Gott in Welt. Festgabe K. Rahner, Bd. 2, Freiburg im Br. 1964, 210-211.

${ }_{25}$ Blachnicki, TPO II 57-66.

${ }^{26}$ F. X. Arnold, Was ist Pastoraltheologie? „Anima” 14(1959) 194-198. Arnold definiuje teologię pastoralną jako ,die Lehre vom kirchlichen Mittlertum und seinen Wirkformen” (Pastoraltheologische Durchblicke. Das Prinzip des Gott-menschlichen und der geschichtliche Weg der Pastoraltheologie, Freiburg-Basel-Wien 1965, s. 14), a zadaniem tej dyscypliny jest wyjaśnić stosunek kościelnego pośrednictwa do zbawczego wydarzenia, które dokonało się historii zbawienia pomiędzy Bogiem a człowiekiem; por. W. Schneider, Das gottmenschliche Prinzip, WPTh III 134.

${ }^{27}$ Por. Arnold, Was ist Pastoraltheologie? s. 194. To związanie z czasem, z konkretnym „tu i teraz”, stanowi proprium jego teologii pastoralnej: ,Jede Zeit - pisał - hat ihre Fragen, ihre Nöte, auf die sie eine Antwort fordert. Darum hat jede Zeit ihr Katechismusproblem, ihr Predigtproblem und ihre liturgische Problematik. Alle diese Aufgaben können immer nur zeitgültig, nie endgültig gelöst werden” (tamże s. 195).

28 „Wenn hier von Kirche und von ihrer Erbauung in die hinein die Rede ist, so ist damit Kirche im Vollsinn ihres dogmatischen Vestandes und personalen Bestandes gemeint" (tamże, s. 196). 
z Jego wolą - przenika czas poprzez posługę Kościoła w słowie, sakramencie i Ofierze"29. Kościół w kontekście zasady bosko-ludzkiej jest narzędziem; posiada więc , drugorzędne znaczenie ${ }^{30} \mathrm{w}$ dialogicznym wydarzeniu bosko-ludzkiego spotkania. Kościół bowiem, jako societas sanctorum, jest podmiotem pośrednictwa zbawczego. W swej historii nie zawsze pozostał wierny służebnemu charakterowi tej posługi, co wynikało zawsze z jednostronnie ujmowanej chrystologii, podnosząc albo boskość Zbawiciela, albo Jego człowieczeństwo. Prowadziło to albo do zagubienia jego wymiaru mistycznego ciała, w którym wszystkie jego członki pełnią funkcję pośredniczącą, albo do podkreślenia znaczenia kościelnego urzędu, a więc ograniczenia działania Kościoła do aktywnej posługi kleru ${ }^{31}$. Arnold wskazał także na potrzebę zachowania przez teologię pastoralną bosko-ludzkiej równowagi. Jej brak może prowadzić do przesadnego wyolbrzymienia znaczenia elementu ludzkiego, co w konsekwencji owocuje negatywnym uprzedmiotowieniem łaski i magią graniczącą czasem z zabobonem lub do zarzucenia znaczenia roli elementu personalnego, co prowadzi do organologicznego (mechanicznego) administrowania środkami laski $^{32}$. Zachwianiu owej „bosko-ludzkiej równowagi” w przekonaniu tybindzkiego Pastoralisty może przeciwdziałać uświadomienie sobie przez Kościół swej narzędnej roli, że zgodnie ze swą istotą pełni funkcję zastępczą, pośredniczącą. Winien zawsze pamiętać o różnicy pomiędzy procesem zbawczym a zbawczym pośrednictwem i ją poważnie traktować: „liturgia, diakonia i martyria są środkami umożliwiającymi osobowe spotkanie Boga z człowiekiem"33.

W przekonaniu Arnolda ważne jest także i to, by Kościół zdawał sobie sprawę z tego, że jego zbawczo pośredniczące zadanie polega na umożliwieniu i aktualizowaniu dialogu pomiędzy wzywającym Bogiem a odpowiadającym na to wezwanie człowiekiem. Jest to według tego teologa służba słowu i wierze ${ }^{34}$, która nie wyczerpuje się tylko w przepowiadaniu. Bóg bowiem nie objawia się jedynie w słowie, lecz także w sakramentach, dzięki którym człowiek w wierze ma udział w historycznym i zbawczym dziele Jezusa ${ }^{35}$.

\section{Przejęcie zasady bosko-ludzkiej przez współczesną polską teologię pas-} toralną i próba jej zaktualizowania. W literaturze polskiej jedynie Sługa Boży,

29 Tamże, s. 197

${ }^{30}$ F. X. Arnold, Grundsätzliches und Geschichtliches zur Theologie der Seelsorge. Das Prinzip des Gott-Menschlichen, Freiburg in Br. 1949, s. 21.

31 Por. Arnold, Seelsorge aus der Mitte der Heilsgeschichte, s. 72-82.

32 Por. tamże s. 20-22.

33 Schneider, Das gottmenschliche Prinzip, s. 135-136.

34 Por. Glaubensverkündigung und Glaubensgemeinschaft, Düsseldorf 1955, s. 31, 43; por. Blachnicki, Pośrednictwo, 139-140; Blachnicki, TPO I 104-111, 117-127.

35 Por. Seelsorge aus der Mitte der Heilsgeschichte, s. 39; por. Blachnicki, TPO I 138-144, 154160. 
ks. F. Blachnicki zajął się krytyczną analizą dorobku Arnolda. Dokonał tego najpierw w swej pracy doktorskiej ${ }^{36}$, a następnie w specjalnym opracowaniu wydanym w księdze pamiątkowej z racji stupięćdziesięciolecia założenia fakultetu teologicznego na uniwersytecie w Tybindze ${ }^{37}$. On także dokonał próby jej zaktualizowania dzięki wprowadzeniu personalistycznej koncentracji w teologii, którą określił mianem personalistyczno-chrystologicznej zasady formalnej teologii pastoralnej i duszpasterstwa.

Analiza dorobku teologiczno-pastoralnego Franciszka Ksawerego Arnolda doprowadziła księdza Blachnickiego do przekonania, że przejął on „zasadnicze tezy Grafa dotyczące podkreślenia natury teologii pastoralnej, jej właściwego przedmiotu i podmiotu, podejmując tym samym przerwaną linię rozwoju eklezjologicznej koncepcji teologii pastoralnej"38. Nadto wypracował i wprowadził do teologii pastoralnej jedną zasadę formalną, która „,w sposób uzasadniony i jednoznaczny określiła istotne elementy i prawa zbawczego pośrednictwa Kościoła”. Tę chrystologiczną zasadę określił jako zasadę bosko-ludzką ${ }^{39}$.

Próba ustalenia przez Księdza Blachnickiego sensu pojęcia zasady boskoludzkiej w piśmiennictwie tego teologa doprowadziła do wniosku, że używał go w trzech różnych znaczeniach: najpierw jest określana „w kategoriach personalistycznych, jako zasada międzyosobowego spotkania i dialogu pomiędzy Bogiem a człowiekiem w Chrystusie", wyznaczając tym samym pośrednictwu zbawczemu Kościoła (tzw. duszpasterstwu) respektowanie personalistycznej i dialogicznej struktury procesu zbawczego ${ }^{40}$, następnie dotyczy ona „współdziałania w dziele zbawienia łaski Bożej i natury wraz z jej wolnością", wyznaczając konieczność kierowania się „zasadą równowagi elementu boskiego i ludzkiego”, która polega na „współdziałaniu łaski i wolnej woli, przybierając postać prawdziwego bosko-ludzkiego synergizmu" ${ }^{\text {"41 }}$, w końcu zasada boskoludzka występuje u Arnolda jako ,zasada chrystologiczna, której sens wyraża się w tym, że Chrystus, Bóg-Człowiek, ma być we wszystkim prototypem kościelnego pośrednictwa zbawczego" 42 .

${ }^{36}$ Por. Pośrednictwo zbawcze Kościoła w ujęciu Franciszka Ksawerego Arnolda. Problem zasady formalnej teologii pastoralnej, Lublin 1965 (mps BKUL).

37 Por. Das Prinzip des Gott-Menschlichen als Formalprinzip der Pastoraltheologie, w: Theologie im Wandel, Münster 1967, 638-646.

38 Tamże, s. 53; por. Kamiński, Wprowadzenie do teologii pastoralnej, s. 37.

${ }^{39}$ Por. Blachnicki, TPO II 57; W. Offele (Das Verständnis der Seelsorge in der pastoraltheologischen Literatur der Gegenwart, Mainz 1966, s. 81 przyp. 4) podaje, że sam Arnold w Seelsorge aus der Mitte der Heilsgeschichte (s. 183) wskazał na F. A. Staudenmeiera (1800-1856), który rozumiał teologię pastoralna jako naukę o bosko-ludzkich działaniach Kościoła. To ujęcie rozwinął później Graf.

${ }^{40}$ Por. Blachnicki, TPO II 58; tenże, Pośrednictwo, s. 34, 36.

${ }^{41}$ Blachnicki, TPO II 58, 59-60; tenże, Pośrednictwo, s. 145.

${ }^{42}$ Blachnicki, TPO II 58, 60; tenże, Pośrednictwo, s. 218-259; tenże, TPO I 227-275. 
Sługa Boży, nie umniejszając w niczym znaczenia tybindzkiego Pastoralisty w rozwoju samej teologii pastoralnej ${ }^{43}$, jak i analizując jego rozumienie procesu zbawczego i kościelnego pośrednictwa zbawczego, zaproponował, by „z dość ogólnikowego i niesprecyzowanego pojęcia «das Gott-Menschliche Prinzip» wyodrębnić bardziej zawężoną i ściślej "określoną zasadę personalistyczną" ${ }^{4}$. Arnold bowiem, „mówiąc o »principium bosko-ludzkim «, ma ciągle na uwadze personalistyczną i dialogową strukturę procesu zbawczego", którą, w przekonaniu księdza Blachnickiego, należy uzupełnić o element chrystologiczny, gdyż w „obecnym porządku świata nie może dojść do spotkania i zjednoczenia z Bogiem, jak tylko przez zetknięcie się z konkretną osobą Jezusa Chrystusa" ${ }^{45}$ : Chrystus bowiem może być nazwany prototypem kościelnego pośrednictwa, jak słusznie podkreśla Arnold $^{46}$, ale jest On przede wszystkim realizatorem tego spotkania i pośrednikiem ${ }^{47}$, jak podkreśla ksiądz Blachnicki, proponując przyjęcie zasady personalistyczno-chrystologicznej zamiast zasady bosko-ludzkiej, wypracowanej przez Arnolda.

Nie oznacza to jednak, że zasada bosko-ludzka, w ujęciu tybindzkiego Pastoralisty nie była charakterystyczna personalistyczną ${ }^{48}$, dialogową i chrystologiczną ${ }^{49}$ strukturą procesu zbawczego, ale nie została ona tak wyodrębnio-

43 „Jego przemyślenia na temat bosko-ludzkiej zasady duszpasterstwa dają nareszcie pastoralistom do ręki - pisał ksiądz Blachnicki - jakieś naukowe i teologiczne kryteria do oceny aktualnych form działalności duszpasterskiej Kościoła i do wysunięcia postulatów co do kierunku ich rozwoju w przyszłości” (Blachnicki, TPO II 61).

${ }^{44}$ Blachnicki, Pośrednictwo, s. 36-37 lub: zasadę personalistyczno-dialogiczną (Blachnicki, TPO II 63; Blachnicki, Das Prinzip des Gott-Menschlichen als Formalprinzip der Pastoraltheologie, s. 651, 656).

45 Blachnicki, Pośrednictwo, s. 252.

${ }^{46}$ Por. Grundsätzliches und Geschichtliches zur Theologie der Seelsorge, s. 7; tenże, Seelsorge aus der Mitte der Heilsgeschichte, s. 15-63, 112.

${ }^{47}$ Por. Blachnicki, Pośrednictwo, s. 243. Warto w związku z tym zwrócić uwagę na książkę E. H. Schillebeeckxa pt. Chrystus Sakrament spotkania z Bogiem (Kraków 1966) oraz uwagi ks. A. Zuberbiera zamieszczone we wstępie do niej ( $O$ tej ksiązce i jej autorze) na temat personalistycznego charakteru sakramentów (s. 7-15).

48 „»Organologicznej《 i niemal naturalno-biologicznej koncepcji pośrednictwa zbawczego Kościoła przeciwstawia Arnold koncepcje duchowo-personalistyczną. Opiera się ona na personalistycznym charakterze procesu zbawczego, który polega na zjednoczeniu z Chrystusem przez akty $\mathrm{z}$ istoty swej duchowe i osobowe tj. przez wiarę i miłość" (Blachnicki, Pośrednictwo, s. 30; tamże s. 36, 216). Por. Blachnicki, TPO II 64; tenże, Das Prinzip des Gott-Menschlichen als Formalprinzip der Pastoraltheologie, s. 639-644, 646-659; Kamiński, Wprowadzenie do teologii pastoralnej, s. 38-40.

49 „Wprawdzie Arnold już na samym wstępie swoich studiów nad „,bosko-ludzką zasadą duszpasterstwa" pojmuje te zasadę w sensie chrystologicznym. Faktycznie jednak [...] dopiero później, w zbiorowej pracy chrystologicznej [...] próbuje ją naświetlić zasadniczo i w rozwoju historycznym z punktu widzenia dogmatu chrystologicznego [...]. Określenie to jest bardzo ogólnikowe [...] ma więc jakiś charakter czysto zewnętrzny, opiera się ono w istocie tylko na podobieństwie zachodzącym pomiędzy jednością natury ludzkiej i boskiej w osobie Jezusa Chrystusa a postulowaną jednościa działania ludzkiego i boskiego w procesie i pośrednictwie zbawczym" 
na i teologicznie uzasadniona, jak dokonał tego Sługa Boży ${ }^{50}$. Sformułował ją następująco: ,zbawcze pośrednictwo Kościoła (jako instytucji), czyli duszpasterstwo, musi być sprawowane w tym celu i w taki sposób, aby uobecniać udzielanie się Boga w Chrystusie przez słowo i sakrament oraz warunkować wolne przyjęcie tego udzielania się w Duchu Świętym przez wiarę i miłość do wzrostu Kościoła (jako społeczności) ${ }^{51}$. Wprowadzenie i połączenie dwóch przymiotników (personalistyczno-chrystologiczna) należy, w przekonaniu księdza Blachnickiego, rozumieć jako wzajemne uzupełnianie się i determinowanie. Oznacza to najpierw, ,ze personalizm należy ostatecznie określić z punktu widzenia dogmatu chrystologicznego, a więc jako personalizm chrystologiczny”, a następnie, ,że w rzeczywistości, objętej dogmatem chrystologicznym, należy uwzględnić wszystkie momenty i aspekty zarówno personalistyczne, jak i dynamiczne, w sensie jakiejś personalistycznej chrystologii" ${ }^{52}$.

\section{*** $*$}

Jednym $\mathrm{z}$ istotnych problemów $\mathrm{w}$ teologii pastoralnej jest wypracowanie zasady formalnej, która miałaby znaczenie konstruktywne dla teologii pastoralnej jako odrębnej pod względem metodologicznym dyscypliny naukowej. Dla Antoniego Grafa, któremu zawdzięczamy „genialny zarys katolickiej teologii praktycznej dziewiętnastego stulecia" ${ }^{53}$, zasadę formalną teologii pastoralnej stanowiło samobudowanie się Kościoła. Zawierała ona w sobie, jak to ujął ksiądz Blachnicki ,wizję Kościoła, wspólnoty w Chrystusie i Duchu Świętym, której budowanie zwłaszcza w gminie lokalnej jest właściwym celem działania Kościoła i jego autorealizacją”. Ta konstatacja sprawia, że w przypadku Grafa „można się pytać tylko o jej udoskonalenie w dalszym rozwoju, a nie o jej słuszność i zasadność w ogóle "54. Ujęcie to zostało jednak porzucone i podjęte dopiero w początkach lat czterdziestych naszego stulecia przez Fran-

(Blachnicki, Pośrednictwo, s. 218-219, 220, 222; tamże s. 224); por. Blachnicki, TPO II 64-65; tenże, Das Prinzip des Gott-Menschlichen als Formalprinzip der Pastoraltheologie, s. 644-659; Kamiński, Wprowadzenie do teologii pastoralnej, s. 38-40.

50 Blachnicki, Pośrednictwo, s. 225-259; tenże, TPO II 66. Została ona przyjęta przez tybinckiego Teologa, który w liście do Sługi Bożego z dnia 17 XII 1967 r. pisal m.in.: „Mit Ihren Ausführungen bin ich ganz einverstanden. Ihre Formulierung entspricht ganz meiner Intention. Ich war selbst nie ganz zufrieden mit der Formulierung »das gott-menschliche Prinzip«. So ich bin sehr froh darüber, daß Sie die Frage weiter geklärt haben” (cyt. za: Blachnicki, TPO II 154-155 przyp. 66).

${ }_{51}$ Blachnicki, TPO II 66; tenże, Das Prinzip des Gott-Menschlichen als Formalprinzip der Pastoraltheologie s. 659.

52 Blachnicki, TPO II 66.

53 N. Mette, Die Tübinger pastoraltheologische Schule, s. 75.

${ }^{54}$ Blachnicki, TPO II s. 51-52. 
ciszka Ksawerego Arnolda, który wzbogacił ją o próbę zakotwiczenia jej w dogmacie chrystologicznym. W swej twórczości teologiczno-pastoralnej sformułował tzw. bosko-ludzką zasadę duszpasterstwa (das Prinzip des Gott-menschlichen), w której, na podstawie studiów teologiczno-historycznych, stanowiących klucz do zrozumienia pasterskiego działania Kościoła i jego form, zawarł przekonanie, że Chrystus Bóg-Człowiek i Pośrednik musi być we wszystkim prototypem kościelnego pośrednictwa zbawczego, czyli duszpasterstwa. Dotyczy to także podstawowych form tego pośrednictwa, które muszą być wydedukowane z pośrednictwa prototypu - Chrystusa. Ujęcie to zostało z kolei przez ks. Franciszka Blachnickiego zawężone i ściślej określone przez zasadę personalistyczną i uzupełnione o element chrystologiczny. W konsekwencji doprowadziło do rozwinięcia zasady bosko-ludzkiej w personalistyczno-chrystologiczną lub personalistyczno-dialogiczną zasadę formalną teologii pastoralnej i duszpasterstwa, które - jak wiemy - spotkało się z aprobatą tybindzkiego Teologa.

\title{
DAS CHRISTOLOGISCHE DOGMA VON CHALCEDON IN DER HEUTIGEN PASTORALTHEOLOGIE
}

\author{
(Zusammenfassung)
}

Eines der wichtigsten Probleme in der Pastoraltheologie bildet die Herausarbeitung eines formalen Prinzips, welches für die Pastoraltheologie als methodologisch besonderes Wissenschaftsgebiet von konstruktiver Bedeutung wäre. Für Anton Graf, dem wir einen ,genialen Abriß der katholischen praktischen Theologie des 19. Jahrhunderts" verdanken, stellte die Selbsterbauung der Kirche das formale Prinzip der Pastoraltheologie dar. Dieses beinhaltete, wie Pater Blachnicki es formulierte, ,eine Vision der Kirche, der Gemeinschaft in Christus und im Heiligen Geist, deren Erbauung insbesondere in der Ortsgemeinde das eigentliche Ziel des Wirkens der Kirche und ihre Selbstverwirklichung darstellt". Deshalb kann im Falle von Graf „nur nach einer Vervollkommnung dieses Prinzips durch Weiterentwicklung gefragt werden und nicht nach seiner Berechtigung und Stichhaltigkeit". Diese Formulierung wurde allerdings verworfen und erst zu Beginn der vierziger Jahre unseres Jahrhunderts von Franz Xaver Arnold neu aufgegriffen, der sie um den Versuch einer Verankerung im christologischen Dogma bereicherte. In seinem pastoraltheologischen Schaffen formulierte er das sog. ,Prinzip des Gott-Menschlichen" in der Seelsorge, mit dem er auf der Basis theologisch-historischer Studien, welche den Schlüssel zum Verständnis der Seelsorgetätigkeit der Kirche und ihrer Formen bilden, seiner Überzeugung Ausdruck verlieh, daß Christus als GottMensch und Mittler in allem der Prototyp der kirchlichen Heilsmittlerschaft, d.h. 
der gesamten Seelsorge, sein muß. Dies betrifft auch die grundlegenden Formen dieser Mittlerschaft, die alle von der Mittlerschaft des Prototyps Christus abgeleitet werden müssen. Dieser Ansatz wurde wiederum von Pater Franciszek Blachnicki enger gefaßt, durch das christologische Element genauer bestimmt und durch das personalistische Prinzip ergänzt. In der Konsequenz führte dies zu einer Weiterentwicklung des gott-menschlichen Prinzips zu einem personalistisch-christologischen oder personalistisch-dialogischen formalen Prinzip der Pastoraltheologie und Seelsorge, was - wie wir wissen - von dem Tübinger Theologen gutgeheißen wurde.

Aus dem Polnischen übersetzt von Herbert Ulrich 